\title{
Dactylosporangium luridum sp. nov., Dactylosporangium luteum sp. nov. and Dactylosporangium salmoneum sp. nov., nom. rev., isolated from soil
}

\section{Correspondence Michael Goodfellow m.goodfellow@ncl.ac.uk}

\author{
Byung-Yong Kim, ${ }^{1,2}$ James E. M. Stach, ${ }^{1}$ Hang-Yeon Weon, ${ }^{2}$ \\ Soon-Wo Kwon ${ }^{2}$ and Michael Goodfellow ${ }^{1}$
${ }^{1}$ Microbial Resources Laboratory, School of Biology, University of Newcastle, Newcastle upon Tyne NE1 7RU, UK
${ }^{2}$ Korean Agricultural Culture Collection, National Academy of Agricultural Science, Rural Development Administration, Suwon 441-707, Republic of Korea

\begin{abstract}
Forty strains isolated from soil taken from a hay meadow were assigned to the genus Dactylosporangium on the basis of colonial properties. 16S rRNA gene sequence analysis showed that the isolates formed a group that was most closely related to the type strain of Dactylosporangium aurantiacum, but well separated from other Dactylosporangium type strains and from 'Dactylosporangium salmoneum' NRRL B-16294. Twelve of 13 representative isolates had identical 16S rRNA gene sequences and formed a subclade that was distinct from corresponding phyletic lines composed of the remaining isolate, strain $B K 63^{\top}$, the ' $D$. salmoneum' strain and the type strains of recognized Dactylosporangium species. DNA-DNA relatedness data indicated that representatives of the multi-membered 16S rRNA gene subclade, isolate $\mathrm{BK}{ }^{\top}$ and the ' $D$. salmoneum' subclade formed distinct genomic species; all of these organisms had chemotaxonomic and morphological properties consistent with their classification in the genus Dactylosporangium. They were also distinguished from one another and from the type strains of recognized Dactylosporangium species based on a range of phenotypic properties. Combined genotypic and phenotypic data showed that isolate $B K 63^{\top}$, isolates $B K 51^{\top}, B K 53$ and BK69, and strain NRRL B-16294 ${ }^{\top}$ should be classified in the genus Dactylosporangium as representing novel species. The names proposed for these species are Dactylosporangium luridum sp. nov. (type strain BK63 ${ }^{\top}=\mathrm{DSM} 45324^{\top}=\mathrm{KACC} 20933^{\top}=\mathrm{NRRL} B-24775^{\top}$ ), Dactylosporangium luteum sp. nov. (type strain BK51 ${ }^{\top}=\mathrm{DSM} 45323^{\top}=\mathrm{KACC} 20899^{\top}=\mathrm{NRRL}$ B-24774 ${ }^{\top}$ ) and Dactylosporangium salmoneum sp. nov., nom. rev. (type strain NRRL B-16294

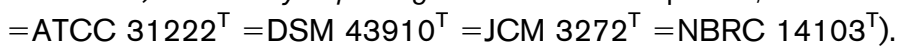

The genus Dactylosporangium was proposed by Thiemann et al. (1967) to accommodate aerobic, filamentous actinomycetes that released motile spores formed in sporangia borne on short sporangiophores carried on the substrate mycelium. At the time of writing, the genus comprises six recognized species: Dactylosporangium aurantiacum (the type species; Thiemann et al., 1967), D. fulvum (Shomura et al., 1986), D. matsuzakiense (Shomura et al., 1980), D. roseum (Shomura et al., 1985), D. thailandense (Thiemann et al., 1967) and D. vinaceum (Shomura et al., 1983); two additional taxa, 'Dactylosporangium salmoneum' and 'D. variesporum', have been cited as species incertae sedis (Vobis,

The GenBank/EMBL/DDBJ accession numbers for the 16S rRNA gene sequences of strains $B K 63^{\top}, B K 51^{\top}$ and NRRL B-16294 ${ }^{\top}$ are FJ973605, FJ973604 and FJ973607, respectively.
1989). Dactylosporangiae form a distinct phyletic branch in the Micromonosporaceae 16S rRNA gene sequence tree (Koch et al., 1996; Thawai et al., 2008), and can be distinguished from other genera classified in the family Micromonosporaceae by using a combination of chemotaxonomic, morphological and phylogenetic data (Vobis, 2006; Ara et al., 2008). In contrast, members of Dactylosporangium species show minimal differences in chemical, morphological and physiological properties and are distinguished mainly on the basis of diffusible pigment and substrate mycelial colours (Vobis, 1989, 2006).

The primary aim of the present investigation was to determine the taxonomic status of a group of filamentous soil actinomycetes that had colonial and morphological properties characteristic of members of the genus 
Dactylosporangium. To this end, the isolates were compared with the type strains of recognized Dactylosporangium species and with 'D. salmoneum' NRRL B-16294 in a polyphasic taxonomic study. The resultant genotypic and phenotypic data showed that the isolates represented two novel Dactylosporangium species. It is also proposed that ' $D$. salmoneum' NRRL B-16294 be recognized as representing a novel species.

Actinomycetes were isolated on plates of Streptomyces isolation medium (per litre distilled water: $0.4 \mathrm{~g}$ casein, $1.0 \mathrm{~g}$ starch, $0.1 \mathrm{~g} \mathrm{CaCO}_{3}, 0.2 \mathrm{~g} \mathrm{KH}_{2} \mathrm{PO}_{4}, 0.5 \mathrm{~g} \mathrm{KNO}$, $0.1 \mathrm{~g} \mathrm{MgSO}_{4}, 15 \mathrm{~g}$ agar), supplemented with cycloheximide $\left(20 \mu \mathrm{g} \mathrm{ml}^{-1}\right)$ and oxytetracycline $\left(20 \mu \mathrm{g} \mathrm{ml}{ }^{-1}\right)$, following inoculation with suspensions of soil taken from Palace Leas meadow hay plot 6 (Atalan et al., 2000) at Cockle Park Experimental Farm, Northumberland, UK (National Grid Reference NZ 200913). Forty isolates that produced orange substrate mycelium characteristic of Dactylosporangium strains were purified and maintained on oatmeal agar (ISP medium 3; Shirling \& Gottlieb, 1966) at room temperature and as suspensions of mycelial fragments in glycerol $(20 \%, \mathrm{v} / \mathrm{v})$ at $-20{ }^{\circ} \mathrm{C}$. rep-PCR, based on the use of BOX-, ERIC- and REP-PCR primers, was used to group and select isolates for the subsequent polyphasic study. Isolate BK63 ${ }^{\mathrm{T}}$, 'D. salmoneum' NRRL B16294 and each of the Dactylosporangium marker strains were clearly separated from one another and from the remaining isolates on the basis of their rep-PCR profiles.

Thirteen strains were taken to represent the taxonomic variation shown by the isolates based on rep-PCR profiles. These isolates, together with the type strains of recognized Dactylosporangium species and 'D. salmoneum' NRRL B16194, were grown in shake flasks of modified Bennett's broth (Jones, 1949) at $28{ }^{\circ} \mathrm{C}$ for 14 days at 150 r.p.m. to obtain biomass for molecular systematic studies. The cultures were checked for purity and harvested by centrifugation. Biomass preparations were washed in $\mathrm{NaCl} / \mathrm{EDTA}$ buffer $(0.1 \mathrm{M}$ EDTA, pH 8.0, 0.1 M NaCl) and stored at $-20{ }^{\circ} \mathrm{C}$ until needed.

The phylogenetic positions of the strains were determined by $16 \mathrm{~S}$ rRNA gene sequence analysis. Genomic DNA, PCR and direct sequencing of the purified products were carried out as described by Tan et al. (2006). The resultant, almostcomplete 16S rRNA gene sequences (1430-1439 nt) were aligned manually, by using the jPHYDIT program (Jeon et al., 2005), against corresponding sequences of representatives of genera classified in the family Micromonosporaceae, retrieved from the GenBank database. Phylogenetic trees were inferred by using the neighbour-joining (Saitou \& Nei, 1987) and maximum-parsimony (Fitch, 1971) algorithms from the MEGA version 3 program (Kumar et al., 2004) and the maximum-likelihood method (Felsenstein, 1981) from the PHYLIP suite of programs (Felsenstein, 1993). The evolutionary distance model of Jukes \& Cantor (1969) was used to generate evolutionary distance matrices for the neighbour-joining algorithm. The topologies of the resultant trees were evaluated in a bootstrap analysis (Felsenstein, 1985) based on 1000 resamplings of the neighbour-joining dataset by using the CONSENSE and SEQBOOT options from the PHYLIP package.

In the 16S rRNA gene sequence tree of representative members of the Micromonosporaceae, the new isolates, ' $D$. salmoneum' NRRL B-16294 and the type strains of recognized Dactylosporangium species formed a welldelineated clade (data not shown). The members of this taxon were most closely related to representatives of the genus Virgisporangium, a relationship that was supported by all of the tree-making algorithms (Fig. 1). All but one of the isolates had identical 16S rRNA gene sequences and formed a distinct subclade together with the type strain of D. aurantiacum; they shared $99.4 \%$ 16S rRNA gene sequence similarity with the latter, a value that corresponded to 9 nucleotide differences over 1435 locations. Relatively high $16 \mathrm{~S}$ rRNA gene sequence similarities were shown with the type strains of D. fulvum (98.1\%), D. matsuzakiense $(98.3 \%)$, D. roseum $(98.2 \%)$, D. thailandense $(98.5 \%)$ and $D$. vinaceum $(98.2 \%)$, as well as with 'D. salmoneum' NRRL B-16294 (98.2\%). The remaining isolate, strain $\mathrm{BK} 63^{\mathrm{T}}$, also shared highest $16 \mathrm{~S}$ rRNA gene sequence similarity with $D$. aurantiacum NRRL B- $8018^{\mathrm{T}}$ (98.9\%; a value equivalent to 16 nucleotide differences across 1436 sites). The new isolates together with the type strain of $D$. aurantiacum formed a subclade that was supported by all of the tree-making algorithms.

A second subclade in the 16S rRNA gene sequence tree contained ' $D$. salmoneum' NRRL B-16294 and the type strains of $D$. matsuzakiense and D. vinaceum. The close relationship between this taxon, the $D$. matsuzakiense subclade and the $D$. aurantiacum subclade was underpinned by all of the tree-making algorithms. ' $D$. salmoneum' NRRL B-16294 and the type strains of $D$. matsuzakiense and D. vinaceum shared $16 \mathrm{~S}$ rRNA gene sequence similarities of 98.9 and $98.8 \%$, respectively, values that corresponded to 16 and 17 nucleotide differences over 1432 locations. D. matsuzakiense DSM $43810^{\mathrm{T}}$ and D. vinaceum DSM $43823^{\mathrm{T}}$ shared $99.6 \% 16 \mathrm{~S}$ rRNA gene similarity, a value equivalent to 6 nucleotide differences over 1468 locations. D. fulvum DSM $43917^{\mathrm{T}}$ and D. roseum DSM $43916^{\mathrm{T}}$, the two most closely related type strains in the genus, exhibited $99.7 \% 16 \mathrm{~S}$ rRNA gene sequence similarity, equivalent to 5 nucleotide differences across 1471 sites. These strains, together with $D$. thailandense DSM $43158^{\mathrm{T}}$, formed a well-delineated taxon, the $D$. thailandense subclade, the integrity of which was underscored by all of the tree-making algorithms and by a bootstrap value of $94 \%$.

Phylogenetic analyses based on partial RNA polymerase $\beta$ subunit $(r p o B)$ gene sequences have provided valuable data in polyphasic studies designed to clarify relationships within and between genera of actinomycetes (Kim et al., 1999, 2004; Goodfellow et al., 2007). In the present study, partial $r p o B$ gene sequences generated for four representative 


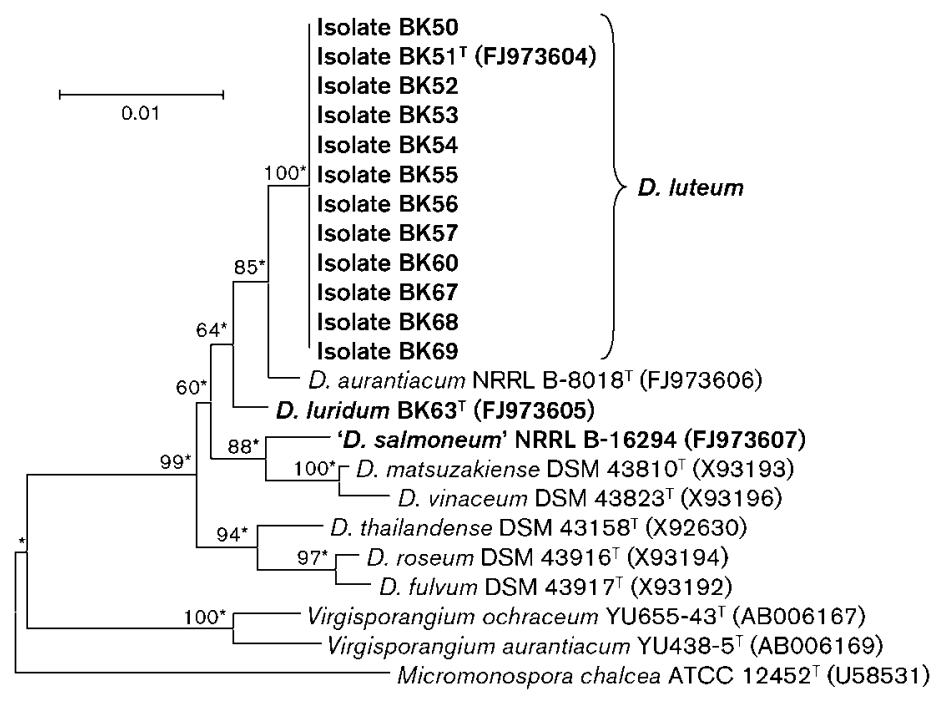

Fig. 1. Neighbour-joining tree (Saitou \& Nei, 1987) based on almost-complete 16S rRNA gene sequences showing the relationships between strains $B K 51^{\top}$ and $B K 63^{\top}$, 'D. salmoneum' NRRL B-16294 and the type strains of recognized Dactylosporangium and Virgisporangium species. Asterisks indicate branches of the tree that were also recovered by using the maximum-likelihood (Felsenstein, 1981) and maximum-parsimony (Kluge \& Farris, 1969) tree-making algorithms. Numbers at nodes indicate levels of bootstrap support (\%); only values $>50 \%$ are shown. The tested strains are given in bold. GenBank accession numbers are given in parentheses. The root position of the neighbour-joining tree was obtained by using Micromonospora chalcea ATCC $12452^{\top}$ as the outgroup. Bar, 0.01 substitutions per site. isolates, strains $\mathrm{BK} 51^{\mathrm{T}}, \mathrm{BK} 53, \mathrm{BK} 63^{\mathrm{T}}$ and $\mathrm{BK} 69$, ' $D$. salmoneum' NRRL B-16294 and the type strains of recognized Dactylosporangium species were compared with corresponding genes of members of genera classified in the family Micromonosporaceae, drawn from GenBank, by using the same tree-making algorithms as above, but with Streptomyces coelicolor A3(2) as the outgroup.

Isolates $\mathrm{BK} 51^{\mathrm{T}}$, BK53 and BK69 had identical rpoB gene sequences and formed a subclade with $D$. aurantiacum NRRL B- $8018^{\mathrm{T}}$ (Fig. 2); the integrity of this taxon was underpinned by all of the tree-making algorithms and by a bootstrap value of $95 \%$. The remaining isolate, strain BK $63^{\mathrm{T}}$, formed a distinct, single-membered subclade at the periphery of the Dactylosporangium rpoB gene sequence tree.

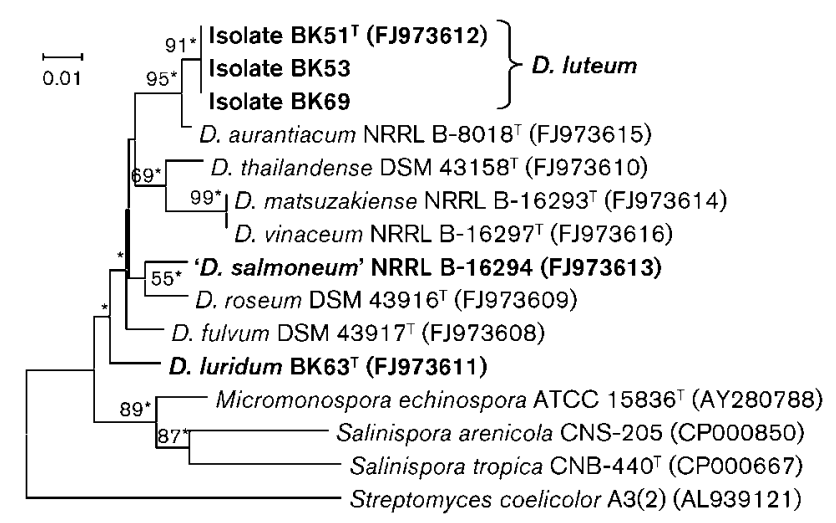

Fig. 2. Neighbour-joining tree based on partial rpo $B$ gene sequences showing the relationships between strains $B K 51^{\top}$, $\mathrm{BK}{ }^{\top}$ ' 'Dactylosporangium salmoneum' NRRL B-16294, the type strains of recognized Dactylosporangium species and members of genera classified in the family Micromonosporaceae. The same tree-making algorithms and criteria were used as detailed in Fig. 1.
'D. salmoneum' NRRL B-16294 also formed a distinct subclade that was associated with D. roseum DSM $43916^{\mathrm{T}}$. These results are in good agreement with those from the 16S rRNA gene sequence analyses as they show that the isolates fall into one distinct multi-membered and one singlemembered clade, although discrepancies are apparent between the topologies of the two trees (see Figs 1 and 2).

DNA-DNA relatedness studies were carried out to determine the finer taxonomic relationships between isolates $\mathrm{BK} 51^{\mathrm{T}}$ and $\mathrm{BK} 63^{\mathrm{T}}$ and 'D. salmoneum' NRRL B-16294 and their closest phylogenetic neighbours (Table 1). Levels of DNA-DNA relatedness between the tested strains were established by measuring the divergence between the thermal denaturation midpoints of homologous and heterologous DNA $\left(\Delta T_{\mathrm{m}}\right)$ following the procedure developed by Gonzalez \& Saiz-Jimenez (2005). Confidence can be placed in the resultant data as comparable results have been obtained when the same strains have featured in thermal denaturation and spectrophotometric studies (Jurado et al., 2005; Goodfellow et al., 2007). $\Delta T_{\mathrm{m}}$ values of 5.0 and $6.0{ }^{\circ} \mathrm{C}$ correspond to DNA-DNA relatedness levels of 60 and $70 \%$, respectively (Rosselló-Mora \& Amann, 2001). DNA G $+C$ contents were determined for all of the strains included in the DNA-DNA experiments by using the procedure described by Gonzalez \& Saiz-Jimenez (2005). The strains had DNA G $+C$ contents within the range $70-$ $74 \mathrm{~mol} \%$ (see Table 4).

Isolate $\mathrm{BK} 51^{\mathrm{T}}$ showed very low $\Delta T_{\mathrm{m}}$ values $\left(0.2-1.6{ }^{\circ} \mathrm{C}\right)$ with isolates BK53 and BK69 (Table 1), values well below the cut-off point recommended for the delineation of genomic species $\left(\Delta T_{\mathrm{m}}>5.0{ }^{\circ} \mathrm{C}\right.$; Wayne et al., 1987). In contrast, isolate $\mathrm{BK} 51^{\mathrm{T}}$ showed $\Delta T_{\mathrm{m}}$ levels well above this cut-off point with isolate BK63 ${ }^{\mathrm{T}}$, 'D. salmoneum' NRRL B16294 and the type strains of $D$. aurantiacum, $D$. matsuzakiense and D. vinaceum. Isolate $\mathrm{BK} 63^{\mathrm{T}}$ also exhibited relatively high $\Delta T_{\mathrm{m}}$ values $\left(5.8-6.2{ }^{\circ} \mathrm{C}\right)$ with the 
Table 1. Levels of DNA-DNA relatedness between isolates $B K 51^{\top}$ and $B K 63^{\top}$ and ' $D$. salmoneum' $N R R L$ B-16294 and their closest phylogenetic neighbours based on $\Delta T_{\mathrm{m}}$ values

\begin{tabular}{|c|c|c|c|}
\hline Strains & $\Delta T_{\mathrm{m}}\left({ }^{\circ} \mathrm{C}\right)$ & DNA-DNA relatedness $(\%)$ & $\begin{array}{l}\text { Nucleotide base differences/total } \\
\text { number of } 16 \mathrm{~S} \text { rRNA nucleotides }\end{array}$ \\
\hline \multicolumn{4}{|l|}{ Isolate $\mathrm{BK} 51^{\mathrm{T}}$ vs: } \\
\hline Isolate BK53 & 1.6 & 82 & $0 / 1444$ \\
\hline Isolate BK69 & 0.2 & 89 & $0 / 1444$ \\
\hline Isolate $\mathrm{BK} 63^{\mathrm{T}}$ & 7.2 & 53 & $11 / 1439$ \\
\hline D. aurantiacum NRRL B- $8018^{\mathrm{T}}$ & 7.2 & 53 & $9 / 1435$ \\
\hline D. matsuzakiense NRRL B-16293 ${ }^{\mathrm{T}}$ & 7.6 & 51 & $24 / 1430$ \\
\hline 'D. salmoneum’ NRRL B-16294 & 5.8 & 61 & $21 / 1431$ \\
\hline D. vinaceum NRRL B- $16297^{\mathrm{T}}$ & 9.5 & 42 & $26 / 1430$ \\
\hline \multicolumn{4}{|l|}{ Isolate $\mathrm{BK} 63^{\mathrm{T}}$ vs: } \\
\hline D. aurantiacum NRRL B- $8018^{\mathrm{T}}$ & 6.2 & 59 & $16 / 1436$ \\
\hline D. matsuzakiense NRRL B-16293 ${ }^{\mathrm{T}}$ & 5.8 & 61 & $22 / 1432$ \\
\hline 'D. salmoneum’ NRRL B-16294 & 6.0 & 60 & $18 / 1433$ \\
\hline D. vinaceum NRRL B-16297 ${ }^{\mathrm{T}}$ & 5.8 & 61 & $23 / 1432$ \\
\hline \multicolumn{4}{|l|}{ 'D. salmoneum' NRRL B-16294 vs: } \\
\hline D. aurantiacum NRRL B- $8018^{\mathrm{T}}$ & 7.5 & 52 & $23 / 1407$ \\
\hline D. matsuzakiense NRRL B-16293 ${ }^{\mathrm{T}}$ & 6.0 & 60 & $16 / 1468$ \\
\hline D. vinaceum NRRL B- $16297^{\mathrm{T}}$ & 6.5 & 57 & $17 / 1476$ \\
\hline
\end{tabular}

type strains of related Dactylosporangium species and with 'D. salmoneum' NRRL B-16294, indicating that it belongs to a distinct genomic species. 'D. salmoneum' NRRL B16294 could also be assigned to a novel genomic species as it exhibited high $\Delta T_{\mathrm{m}}$ values $\left(5.8-7.5^{\circ} \mathrm{C}\right)$ with its nearest neighbours, namely D. matsuzakiense NRRL B-16293 ${ }^{\mathrm{T}}$ and D. vinaceum NRRL B-16297 ${ }^{\mathrm{T}}$.

Biomass for chemotaxonomic studies was prepared by growing representative isolates $\mathrm{BK} 51^{\mathrm{T}}$ and $\mathrm{BK} 63^{\mathrm{T}}$, ' $D$. salmoneum' NRRL B-16294 and the type strains of recognized Dactylosporangium species in modified Bennett's broth at 150 r.p.m. for 21 days at $28^{\circ} \mathrm{C}$; cells were harvested by centrifugation, washed in distilled water, recentrifuged and freeze-dried. Standard procedures were used to extract and analyse the isomers of diaminopimelic acid (Staneck \& Roberts, 1974), isoprenoid quinones (Collins, 1994), muramic acid type (Uchida et al., 1999), polar lipids (Minnikin et al., 1984) and whole-organism sugars (Schaal, 1985), with appropriate controls. Cellular fatty acids were extracted, methylated and analysed by GC by using the standard Sherlock MIDI (Microbial Identification) system (Sasser, 1990) and mycolic acids were identified by using the TLC procedure introduced by Minnikin et al. (1975).

All of the organisms contained mixtures of 3-hydroxy and meso-diaminopimelic acid, $\mathrm{N}$-glycolylmuramic acid, hexahydrogenated and octahydrogenated menaquinones with nine isoprene units $\left[\mathrm{MK}-9\left(\mathrm{H}_{6}\right)\right.$ and $\left.\mathrm{MK}-9\left(\mathrm{H}_{8}\right)\right]$ as predominant menaquinones and arabinose, galactose, glucose, mannose and xylose in whole-organism hydrolysates; mycolic acids were not found. The isolates contained iso- $\mathrm{C}_{15: 0}$ and iso- $\mathrm{C}_{16: 0}$ as predominant fatty acids with varying kinds and proportions of minor compounds and diphosphatidylglycerol, phosphatidylethanolamine, phosphatidylinositol and phosphatidylglycerol as major polar lipids (phospholipid pattern type 2 sensu Lechevalier et al., 1977) with a discontinuous distribution of phosphatidylinositol mannosides, an unknown aminolipid and an unknown phospholipid (Table 2). These results are in good agreement with those of members of the genus Dactylosporangium (Kroppenstedt, 1985; Vobis, 2006).

Isolates $\mathrm{BK} 51^{\mathrm{T}}$ and $\mathrm{BK} 63^{\mathrm{T}}$ and ' $D$. salmoneum' NRRL B-16294 were grown on tryptone-yeast extract, yeast extract-malt extract, oatmeal, inorganic salts-starch, glycerol-asparagine, peptone-yeast extract-iron and tyrosine agars (ISP media 1-7, respectively; Shirling \& Gottlieb, 1966) for 21 days at $28{ }^{\circ} \mathrm{C}$. Colonies growing on these media were examined by eye to determine substrate mycelial pigmentation and the colour of any diffusible pigments; colours were recorded by using National Bureau of Standards (NBS) Colour Name Charts (Kelly, 1958; NBS, 1964). Peptone-yeast extract-iron and tyrosine agar plates were examined to determine whether the strains produced melanin pigments. The strains were also examined to establish whether they grew on LuriaBertani, nutrient and trypticase soy agars (Sambrook et al., 1989) after incubation at $28{ }^{\circ} \mathrm{C}$ for 3 weeks.

All of the strains grew well on inorganic salts-starch, oatmeal and tyrosine agar plates, producing a range of substrate mycelial colours but relatively few diffusible pigments (Table 3 ). The type strains of $D$. roseum, $D$. thailandense and D. vinaceum together with 'D. salmoneum' NRRL B-16294 grew well on all of the media except glycerol-asparagine agar. In contrast, isolates $\mathrm{BK} 51^{\mathrm{T}}$ and $\mathrm{BK} 63^{\mathrm{T}}$ grew poorly on glycerol-asparagine, peptone-yeast 
Table 2. Chemotaxonomic properties of strains $B K 51^{\top}$ and $B K 63^{\top}$, 'D. salmoneum' NRRL B-16294 and the type strains of recognized Dactylosporangium species

Strains: $1, \mathrm{BK} 51^{\mathrm{T}} ; 2, \mathrm{BK} 63^{\mathrm{T}}$; 3, D. aurantiacum NRRL B-8018 ${ }^{\mathrm{T}}$, 4, D. fulvum DSM 43917 $;$ 5, D. matsuzakiense NRRL B-16293 ${ }^{\mathrm{T}}$; 6 , D. roseum DSM $43916^{\mathrm{T}}$; 7, 'D. salmoneum' NRRL B-16294; 8, D. thailandense DSM $43158^{\mathrm{T}}$; 9, D. vinaceum NRRL B-16297 ${ }^{\mathrm{T}}$. All data were acquired in the present study. - , Not detected.

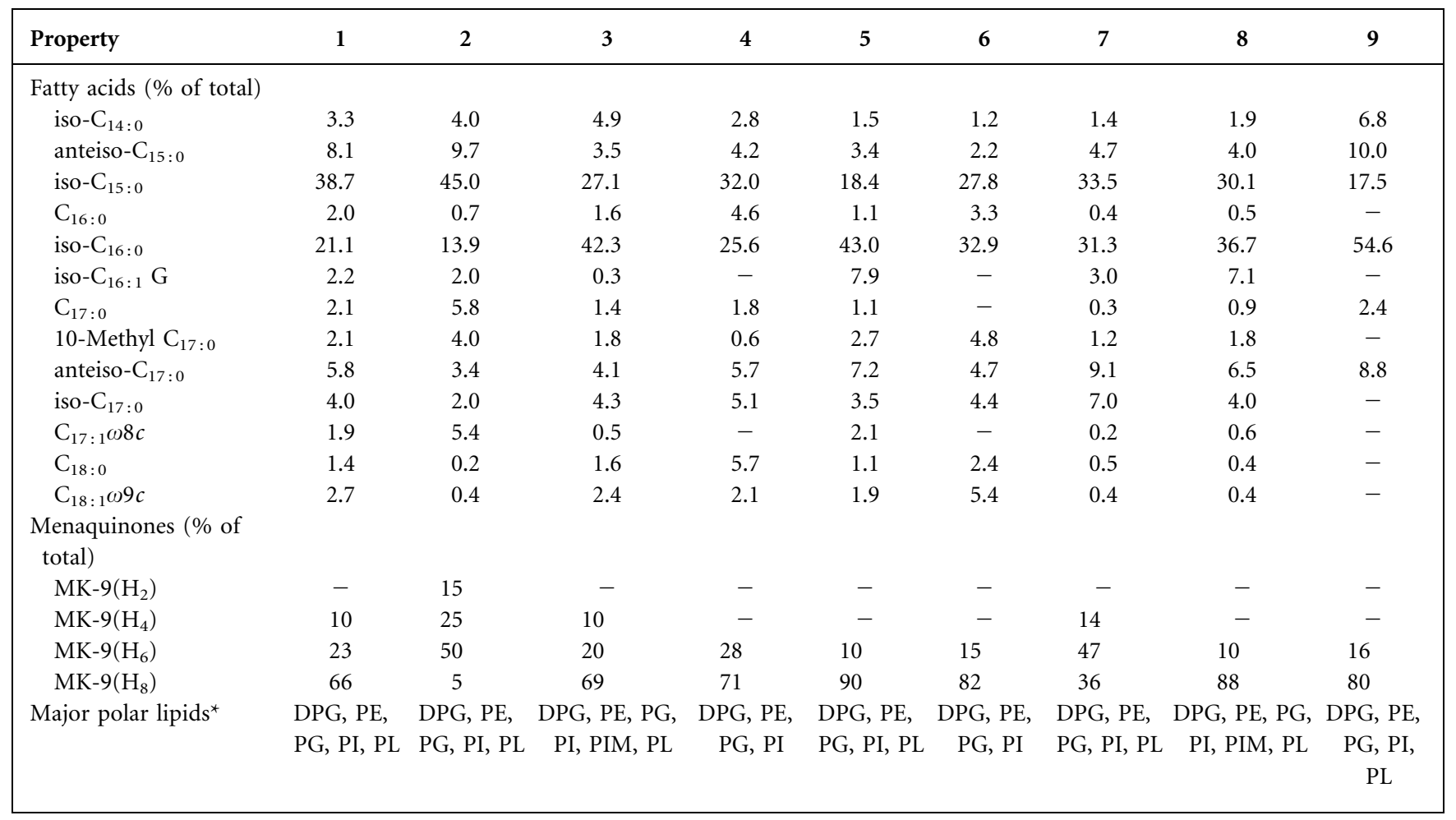

${ }^{\star}$ DPG, Diphosphatidylglycerol; PE, phosphatidylethanolamine; PG, phosphatidylglycerol; PI, phosphatidylinositol; PIM, phosphatidylinositol mannosides; PL, unknown phospholipid.

extract-iron, tryptone-yeast extract and yeast extract-malt extract agar plates. In general, few of the organisms produced soluble pigments on the agar media, although $D$. vinaceum NRRL B-16297 ${ }^{\mathrm{T}}$ formed soluble pigments on all of these media. It is also interesting that isolates $B K 51^{\mathrm{T}}$ and $\mathrm{BK} 63^{\mathrm{T}}$ could be distinguished by the colour of the substrate mycelium that they produced on the various media.

Isolates $\mathrm{BK} 51^{\mathrm{T}}$ and $\mathrm{BK} 63^{\mathrm{T}}$ together with ' $D$. salmoneum' NRRL B-16294 were examined for micromorphological properties on 3-week-old glycerol-asparagine, oatmeal, tyrosine and yeast extract-malt extract agar plates by using a Nikon Optiphot light microscope fitted with a longworking-distance objective. In addition, gold-coated, dehydrated preparations from the plates were examined by using a Cambridge Stereoscan 240 scanning electron microscope following the procedure described by O'Donnell et al. (1993). Preparations from oatmeal agar plates were flooded with sterile water, left for $60 \mathrm{~min}$ and then examined for the presence of motile spores with a light microscope. All of the strains formed irregular branched substrate hyphae $(0.3-0.7 \mu \mathrm{m}$ in diameter), which penetrated the agar. Similarly, all three strains formed sporangia, which released motile spores. Motile spores were formed in finger-like, short, narrow sporangia produced directly on the substrate mycelium (Fig. 3). They also formed globose bodies with smooth surfaces at the top of short sporophores on substrate hyphae.

Isolates $\mathrm{BK} 51^{\mathrm{T}}, \mathrm{BK} 53, \mathrm{BK} 63^{\mathrm{T}}$ and $\mathrm{BK} 69$, 'D. salmoneum' NRRL B-16294 and the type strains of recognized Dactylosporangium species were examined for a broad range of phenotypic properties by using the media and methods described by Goodfellow et al. (1997). All of the strains were positive for catalase, degraded aesculin and xylan, utilized glycogen, $(-)$-D-glucose and $(-)$-sucrose as sole carbon sources, and were sensitive to novobiocin $(8 \mu \mathrm{g}$ $\mathrm{ml}^{-1}$ ) and rifampicin $\left(16 \mu \mathrm{g} \mathrm{ml}^{-1}\right)$. All were negative for nitrite reduction, did not degrade adenine, cellulose, chitin, guanine, hypoxanthine, pectin, tributyrin, Tween 20, uric acid or xanthine, did not use $(+)$-L-lactic acid, (-)-Lsorbose, oxalic acid or (-)-D-ribose as sole carbon sources and did not grow in the presence of $3 \%(\mathrm{w} / \mathrm{v}) \mathrm{NaCl}$ or $0.05 \%(\mathrm{w} / \mathrm{v})$ lysozyme.

Isolates $\mathrm{BK} 51^{\mathrm{T}}$, BK53 and BK69 had identical phenotypic profiles that served to distinguish them from isolate $B K 63^{\mathrm{T}}$, 
Table 3. Growth and cultural characteristics of strains $B K 51^{\top}$ and $B K 63^{\top}$, ' $D$. salmoneum' NRRL B-16294 and the type strains of recognized Dactylosporangium species

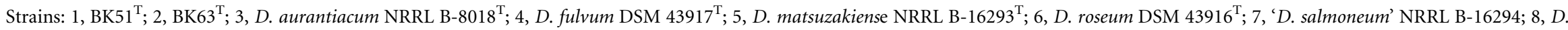
thailandense DSM $43158^{\mathrm{T}}$; 9, D. vinaceum NRRL B- $16297^{\mathrm{T}}$. Data were obtained in this study.

\begin{tabular}{|c|c|c|c|c|c|c|c|c|c|}
\hline Culture medium & 1 & 2 & 3 & 4 & 5 & 6 & 7 & 8 & 9 \\
\hline \multicolumn{10}{|c|}{ Glycerol-asparagine agar } \\
\hline Growth & Poor & Poor & Poor & Poor & Poor & Poor & Moderate & Moderate & Poor \\
\hline Substrate mycelium & Orange & Light yellow & Light yellow & Light yellow & Orange & Light yellow & Light yellow & Light yellow & Orange \\
\hline Soluble pigment & None & None & None & None & None & None & None & None & Light brown \\
\hline \multicolumn{10}{|c|}{ Inorganic salts-starch agar } \\
\hline Growth & Abundant & Moderate & Abundant & Abundant & Abundant & Abundant & Abundant & Abundant & Abundant \\
\hline Substrate mycelium & Orange & Light yellow & Light yellow & Brown & Reddish brown & Light yellow & Light orange & Light brown & Deep purple \\
\hline Soluble pigment & None & None & None & Light brown & None & None & None & Light brown & Black purple \\
\hline \multicolumn{10}{|l|}{ Oatmeal agar } \\
\hline Growth & Abundant & Moderate & Abundant & Abundant & Abundant & Abundant & Abundant & Abundant & Abundant \\
\hline Substrate mycelium & Orange & Light yellow & Orange & Yellow & Reddish orange & Orange & Deep orange & Light brown & Purple \\
\hline Soluble pigment & None & None & None & Light brown & None & None & None & Light brown & Black purple \\
\hline \multicolumn{10}{|c|}{ Peptone-yeast extract-iron agar } \\
\hline Growth & Poor & Poor & Poor & Poor & Poor & Moderate & Moderate & Moderate & Moderate \\
\hline Substrate mycelium & Orange & Light yellow & Yellow & Yellow & Orange & Orange & Yellow & Orange & Reddish orange \\
\hline Soluble pigment & None & None & None & None & None & None & None & None & Brown \\
\hline \multicolumn{10}{|c|}{ Tryptone-yeast extract agar } \\
\hline Growth & Poor & Poor & Moderate & Moderate & Moderate & Moderate & Abundant & Abundant & Moderate \\
\hline Substrate mycelium & Orange & Light yellow & Orange & Light brown & Orange & Orange & Yellow & Orange & Reddish brown \\
\hline Soluble pigment & None & None & None & None & None & None & None & None & Brown \\
\hline \multicolumn{10}{|l|}{ Tyrosine agar } \\
\hline Growth & Moderate & Moderate & Moderate & Moderate & Moderate & Moderate & Moderate & Moderate & Moderate \\
\hline Substrate mycelium & Orange & Light yellow & Orange & Reddish yellow & Light brown & Light yellow & Light brown & Yellow & Reddish orange \\
\hline Soluble pigment & Light brown & None & Light brown & None & Light brown & None & None & None & Light brown \\
\hline \multicolumn{10}{|c|}{ Yeast extract-malt extract agar } \\
\hline Growth & Poor & Poor & Moderate & Abundant & Moderate & Moderate & Abundant & Abundant & Moderate \\
\hline Substrate mycelium & Orange & Light yellow & Orange & Light brown & Orange & Orange & Yellow & Orange & Reddish brown \\
\hline Soluble pigment & None & None & None & None & None & None & None & Light yellow & Light brown \\
\hline
\end{tabular}




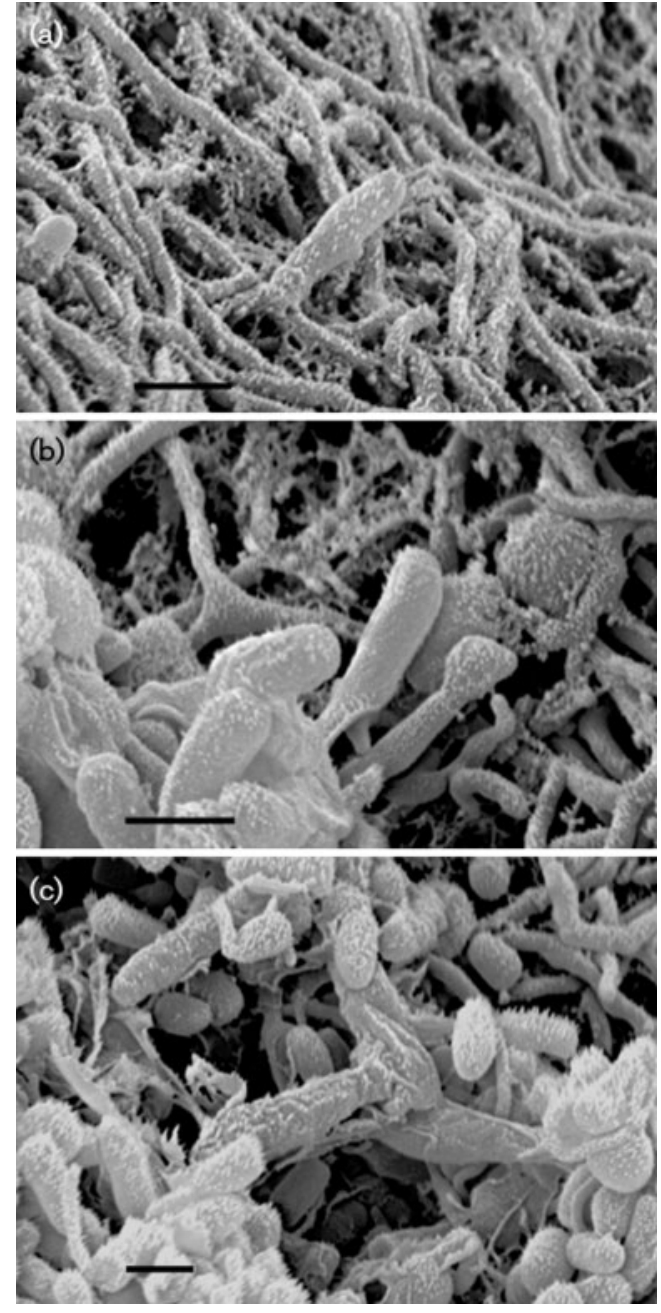

Fig. 3. Scanning electron micrographs of isolate $B K 51^{\top}$ grown on ISP 2 medium for 2 weeks (a), isolate $B K 63^{\top}$ grown on ISP 7 medium for 2 weeks (b) and ' $D$. salmoneum' NRRL B-16294 grown on ISP 7 medium for 8 weeks (c). Bars, $1.0 \mu \mathrm{m}$.

'D. salmoneum' NRRL B-16294 and the type strains of recognized Dactylosporangium species (Table 4). Indeed, these three isolates were the only strains to use $(+)$-Darabitol as a sole carbon source and to be unable to produce $\mathrm{H}_{2} \mathrm{~S}$ or degrade Tween 80. Similarly, unlike most of the other strains, they utilized adonitol, (+)-Larabinose, dextrin, $(-)$-D-fructose and $(+)$-melibiose as sole carbon sources, but were unable to hydrolyse gelatin or to grow at $37{ }^{\circ} \mathrm{C}$. Isolate BK63 ${ }^{\mathrm{T}}$ and 'D. salmoneum' NRRL B-16294 could also readily be separated from one another and from the Dactylosporangium type strains, notably by the inability of strain $\mathrm{BK} 63^{\mathrm{T}}$ to metabolize most of the sole carbon sources and by the activity of 'D. salmoneum' NRRL B-16294 in the degradation tests.

The genotypic and phenotypic data clearly indicate that isolates $\mathrm{BK} 51^{\mathrm{T}}, \mathrm{BK} 53$ and $\mathrm{BK} 69$, isolate $\mathrm{BK} 63^{\mathrm{T}}$ and ' $D$. salmoneum' NRRL B-16294 represent three new centres of taxonomic variation in the genus Dactylosporangium. It is therefore proposed that these strains be classified in the genus Dactylosporangium as representing Dactylosporangium luteum sp. nov., Dactylosporangium luridum sp. nov. and Dactylosporangium salmoneum, respectively. The genotypic data acquired on isolates BK50, BK52, BK54-BK57, BK60, BK67 and BK68 are consistent with their assignment to $D$. luteum.

\section{Description of Dactylosporangium luridum sp. nov.}

Dactylosporangium luridum (lu'ri.dum. L. neut. adj. luridum pale yellow).

Aerobic, Gram-stain-positive, motile actinomycete that forms branched, pale-yellow mycelium on inorganic saltsstarch and oatmeal agars. Short, narrow finger-like sporangia $(1.0-1.2 \times 2.0-2.5 \mu \mathrm{m})$, which release motile spores, are formed on glycerol-asparagine and tyrosine agars. Globose bodies with smooth surfaces are produced on short sporophores arising from substrate hyphae. Melanin pigments are not formed on either peptone-yeast extract-iron or tyrosine agars. Grows well on inorganic salts-starch, oatmeal and tyrosine agars, but poorly on glycerol-asparagine, peptone-yeast extract-iron, tryptoneyeast extract and yeast extract-malt extract agars. Grows well between 20 and $30{ }^{\circ} \mathrm{C}$ (optimally around $28{ }^{\circ} \mathrm{C}$ ) and at $\mathrm{pH}$ 4-9 (optimally around $\mathrm{pH}$ 7). Additional phenotypic properties are given in the main text and in Table 4. Has chemotaxonomic properties consistent with its classification in the genus Dactylosporangium, and forms a distinct phyletic line in the Dactylosporangium 16S rRNA gene sequence tree. The DNA G $+\mathrm{C}$ content of the type strain is $70 \mathrm{~mol} \%$.

The type strain, BK63 ${ }^{\mathrm{T}}\left(=\mathrm{DSM} 45324^{\mathrm{T}}=\mathrm{KACC} 20933^{\mathrm{T}}\right.$ $=$ NRRL B $-24775^{\mathrm{T}}$ ), was isolated from a soil sample taken from Palace Leas meadow hay plot 6 at Cockle Park Experimental Farm, Northumberland, UK.

\section{Description of Dactylosporangium luteum sp. nov.}

Dactylosporangium luteum (lu'te.um. L. neut. adj. luteum orange-yellow, flame-coloured).

Aerobic, Gram-stain-positive, motile actinomycete that forms branched, orange-yellow mycelium on oatmeal and inorganic salts-starch agars. Short, narrow finger-like sporangia $(1.0-1.2 \times 2.0-2.5 \mu \mathrm{m})$, which release motile spores, are formed on glycerol-asparagine, tyrosine and yeast extract-malt extract agars. Globose bodies with smooth surfaces are produced on short sporophores arising from substrate hyphae. Melanin pigments are not formed on either peptone-yeast extract-iron or tyrosine agars. Grows well on inorganic salts-starch, oatmeal and tyrosine agars, but poorly on glycerol-asparagine, peptone-yeast extractiron, tryptone-yeast extract and yeast extract-malt extract agars. Grows well between 15 and $30{ }^{\circ} \mathrm{C}$ (optimally around 
Table 4. Differential phenotypic characteristics between strains $B K 51^{\top}$ and $B K 63^{\top}$, 'D. salmoneum' NRRL B-16294 and the type strains of recognized Dactylosporangium species

Strains: 1, BK51 (identical results for strains BK53 and BK69); 2, BK63 ${ }^{\mathrm{T}} ; 3$, D. aurantiacum NRRL B-8018 ${ }^{\mathrm{T}} ; 4$, D. fulvum DSM $43917^{\mathrm{T}} ; 5, D$. matsuzakiense NRRL B-16293 ${ }^{\mathrm{T}}$; 6, D. roseum DSM 43916 ${ }^{\mathrm{T}}$; 7, 'D. salmoneum' NRRL B-16294; 8, D. thailandense DSM 43158 ${ }^{\mathrm{T}} ; 9$, D. vinaceum NRRL $\mathrm{B} 16297^{\mathrm{T}}$. All data were acquired in the present study.

\begin{tabular}{|c|c|c|c|c|c|c|c|c|c|}
\hline Characteristic & 1 & 2 & 3 & 4 & 5 & 6 & 7 & 8 & 9 \\
\hline \multicolumn{10}{|l|}{ Biochemical tests } \\
\hline Allantoin hydrolysis & - & - & - & - & - & + & - & + & - \\
\hline Coagulation and peptonization of milk & - & - & - & - & - & - & - & - & + \\
\hline Hydrogen sulfide production & - & + & + & + & + & + & + & + & + \\
\hline Nitrate reduction & + & + & + & - & - & + & + & - & - \\
\hline Urease production & - & - & + & + & - & - & - & + & + \\
\hline \multicolumn{10}{|l|}{ Degradation tests } \\
\hline Arbutin & + & - & + & + & + & + & + & + & + \\
\hline Casein & - & - & - & - & - & + & + & - & + \\
\hline DNA & - & - & + & + & - & - & + & - & - \\
\hline Elastin & - & - & + & - & - & + & - & - & - \\
\hline Gelatin & - & - & + & + & - & + & + & + & + \\
\hline RNA & - & - & - & - & - & - & + & - & - \\
\hline Starch & + & + & - & + & + & - & + & + & + \\
\hline Tween 40 & - & - & - & + & + & + & + & + & + \\
\hline Tween 60 & - & + & + & + & + & + & + & + & + \\
\hline Tween 80 & - & - & - & + & + & - & + & + & - \\
\hline \multicolumn{10}{|l|}{ Sole carbon source utilization $(1.0 \%, \mathrm{w} / \mathrm{v})$} \\
\hline Adonitol & + & - & - & + & - & - & + & - & - \\
\hline$(+)$-L-Arabinose & + & - & - & - & - & - & + & - & - \\
\hline (+)-D-Arabitol & + & - & - & - & - & - & - & - & - \\
\hline (+)-Cellobiose & + & - & + & + & - & + & + & + & - \\
\hline Dextrin & + & - & - & + & - & - & + & - & - \\
\hline (-)-D-Fructose & + & - & - & - & - & - & + & + & - \\
\hline (+)-D-Galactose & + & - & - & + & - & - & + & + & - \\
\hline Glycerol & + & - & + & + & - & - & + & - & - \\
\hline myo-Inositol & - & - & - & - & - & - & + & - & - \\
\hline Inulin & + & - & + & + & - & + & + & + & + \\
\hline$(+)$-Lactose & + & - & + & - & - & - & + & + & - \\
\hline (+)-Maltose & + & - & - & - & - & + & + & + & - \\
\hline (+)-D-Mannitol & + & - & - & + & - & - & + & + & - \\
\hline (+)-D-Mannose & + & - & - & - & - & + & + & + & - \\
\hline$(+)$-Melibiose & + & - & + & - & - & - & + & - & - \\
\hline Methyl $\alpha$-D-glucoside & + & - & + & + & - & - & + & + & - \\
\hline (+)-Raffinose & + & - & + & + & - & + & + & + & - \\
\hline (-)-L-Rhamnose & + & - & + & - & - & - & + & + & - \\
\hline Salicin & - & - & + & + & - & - & + & - & - \\
\hline Starch & + & + & + & + & + & - & + & + & + \\
\hline (+)-Trehalose & + & + & + & + & - & - & + & + & - \\
\hline (+)-D-Xylose & + & + & + & + & - & - & + & + & - \\
\hline \multicolumn{10}{|l|}{ Sole carbon source utilization $(0.1 \%, \mathrm{w} / \mathrm{v})$} \\
\hline Citric acid & + & - & - & - & - & - & + & + & - \\
\hline$(+)$-L-Lactic acid & + & - & - & + & - & - & - & + & - \\
\hline Malic acid & + & - & - & + & - & + & + & + & - \\
\hline Propionic acid & + & - & - & + & - & + & + & - & - \\
\hline Pyruvic acid & + & - & + & + & + & + & + & + & - \\
\hline (+)-L-Tartaric acid & + & - & - & + & - & - & + & + & - \\
\hline \multicolumn{10}{|l|}{ Growth at: } \\
\hline $15{ }^{\circ} \mathrm{C}$ & + & - & + & - & + & - & - & + & - \\
\hline $37^{\circ} \mathrm{C}$ & - & - & + & + & + & + & + & + & - \\
\hline $\mathrm{pH} 4.0$ & - & + & - & - & + & + & + & + & - \\
\hline $\mathrm{pH} 10.0$ & + & - & - & + & - & - & + & + & - \\
\hline
\end{tabular}


Table 4. cont.

\begin{tabular}{|c|c|c|c|c|c|c|c|c|c|}
\hline Characteristic & 1 & 2 & 3 & 4 & 5 & 6 & 7 & 8 & 9 \\
\hline Production of melanin pigments on tyrosine agar & + & + & + & - & - & - & - & - & + \\
\hline Growth in the presence of $1.5 \% \mathrm{NaCl}(\mathrm{w} / \mathrm{v})$ & + & + & - & - & + & - & + & - & - \\
\hline Ampicillin (4) & - & - & - & - & + & - & + & + & + \\
\hline Cephaloridine (2) & - & - & - & - & + & - & + & + & - \\
\hline Chloramphenicol (8) & - & - & - & + & - & - & - & + & - \\
\hline Clindamycin (8) & + & - & + & + & + & - & + & + & - \\
\hline Gentamicin (8) & + & - & + & + & + & - & + & + & + \\
\hline Kanamycin (8) & - & - & - & - & + & - & + & - & + \\
\hline Lincomycin (8) & + & - & + & + & + & - & + & + & + \\
\hline Oxytetracycline (8) & - & - & + & + & + & - & + & + & - \\
\hline Penicillin G (2) & + & - & - & - & + & + & + & + & + \\
\hline DNA G $+C$ content $(\mathrm{mol} \%)$ & 74 & 70 & 73 & 71 & 73 & 73 & 73 & 71 & 73 \\
\hline
\end{tabular}

$28{ }^{\circ} \mathrm{C}$ ) and at $\mathrm{pH}$ 5-10 (optimally around $\mathrm{pH}$ 7). Additional phenotypic properties are detailed in the main text and in Table 4. Has chemotaxonomic properties consistent with its classification in the genus Dactylosporangium, and forms a distinct phyletic line in the Dactylosporangium 16S rRNA gene sequence tree. The DNA $\mathrm{G}+\mathrm{C}$ content of the type strain is $74 \mathrm{~mol} \%$.

The type strain, BK51 ${ }^{\mathrm{T}}\left(=\mathrm{DSM} 45323^{\mathrm{T}}=\right.$ KACC $20899^{\mathrm{T}}$ $=$ NRRL B-24774 ${ }^{\mathrm{T}}$ ), was isolated from a soil sample taken from Palace Leas meadow hay plot 6 at Cockle Park Experimental Farm, Northumberland, UK. BK50, BK52, BK54-BK57, BK60, BK67 and BK68 are additional strains of the species.

\section{Description of Dactylosporangium salmoneum (ex Celmer et al. 1978) sp. nov., nom. rev.}

Dactylosporangium salmoneum (sal.mo.ne' um. L. n. salmo onis salmon; L. adj. suff. -eus $-a-u m$ suffix used with various meanings; N.L. neut. adj. salmoneum salmoncoloured).

The description is based on data from the present study and from Celmer et al. (1978). Aerobic, Gram-stainpositive, motile actinomycete that forms branched, orange mycelium on inorganic salts-starch and oatmeal agars. Numerous sporangia are formed on calcium malate plates. Sporangia are enlarged slightly towards the apex $(1.5 \times 5.5 \mu \mathrm{m})$, are dactyloform and contain three to four spores. Spores are mainly elliptical $(1.1-1.6 \times 2.2-2.7 \mu \mathrm{m})$ and are motile. Globose bodies with smooth surfaces are formed at the top of short sporophores on substrate hyphae. Melanin pigments are not produced on either peptone-yeast extract-iron or tyrosine agars. Good growth is shown on glycerol-asparagine, inorganic salts-starch, oatmeal, peptone-yeast extract-iron, tryptone-yeast extract, tyrosine and yeast extract-malt extract agars; grows poorly on Luria-Bertani, nutrient and trypticase soy agars. Grows well between 20 and $37{ }^{\circ} \mathrm{C}$ (optimally around $28{ }^{\circ} \mathrm{C}$ ) and at $\mathrm{pH}$ 4-10 (optimally around $\mathrm{pH} 7$ ). Additional phenotypic properties are detailed in the main text and in Table 4. Has chemotaxonomic properties consistent with its classification in the genus Dactylosporangium, and forms a distinct phyletic line in the Dactylosporangium 16S rRNA gene sequence tree. The DNA G $+\mathrm{C}$ content of the type strain is $73 \mathrm{~mol} \%$.

The type strain, NRRL B-16294 ${ }^{\mathrm{T}}\left(=\mathrm{ATCC} 31222^{\mathrm{T}}=\mathrm{DSM}\right.$ $43910^{\mathrm{T}}=\mathrm{JCM} 3272^{\mathrm{T}}=\mathrm{NBRC} 14103^{\mathrm{T}}$ ), was isolated from soil in Japan.

\section{Acknowledgements}

B.-Y.K gratefully acknowledges receipt of an Overseas Research Scholarship, a Newcastle University International Postgraduate Scholarship and funding from the National Institute for International Education, Korea. We are indebted to the ARS Culture Collection, Peoria, IL, USA, for providing the Dactylosporangium type strains and the 'D. salmoneum' strain and to Dr Jean Euzéby for his invaluable advice on naming the novel species.

\section{References}

Ara, I., Bakir, M. A. \& Kudo, T. (2008). Transfer of Catellatospora koreensis Lee et al. 2000 as Catelliglobosispora koreensis gen. nov., comb. nov. and Catellatospora tsunoense Asano et al. 1989 as Hamadaea tsunoensis gen. nov., comb. nov., and emended description of the genus Catellatospora Asano and Kawamoto 1986 emend. Lee and Hah 2002. Int J Syst Evol Microbiol 58, 1950-1960.

Atalan, E., Manfio, G. P., Ward, A. C., Kroppenstedt, R. M. \& Goodfellow, M. (2000). Biosystematic studies on novel streptomycetes from soil. Antonie van Leeuwenhoek 77, 337-353. 
Celmer, W. D., Cullen, W. P., Moppett, C. E., Routien, J. B., Jefferson, M. T., Shibakawa, R. \& Tone, J. (1978). Polycyclic ether antibiotic produced by new species of Dactylosporangium. US Patent 4,081,532.

Collins, M. D. (1994). Isoprenoid quinones. In Chemical Methods in Prokaryotic Systematics, pp. 265-309. Edited by M. Goodfellow \& A. G. O'Donnell. Chichester: Wiley.

Felsenstein, J. (1981). Evolutionary trees from DNA sequences: a maximum likelihood approach. J Mol Evol 17, 368-376.

Felsenstein, J. (1985). Confidence limits on phylogenies: an approach using the bootstrap. Evolution 39, 783-791.

Felsenstein, J. (1993). PHYLIP (phylogeny inference package), version 3.5c. Distributed by the author. Department of Genome Sciences, University of Washington, Seattle, USA.

Fitch, W. M. (1971). Toward defining the course of evolution: minimum change for a specific tree topology. Syst Zool 20, 406-416.

Gonzalez, J. M. \& Saiz-Jimenez, C. (2005). A simple fluorimetric method for the estimation of DNA-DNA relatedness between closely related microorganisms by thermal denaturation temperatures. Extremophiles 9, 75-79.

Goodfellow, M., Brown, A. B., Cai, J. P., Chun, J. S. \& Collins, M. D. (1997). Amycolatopsis japonicum sp. nov., an actinomycete producing $(S, S)-N, N^{\prime}$-ethylenediaminedisuccinic acid. Syst Appl Microbiol 20, $78-84$.

Goodfellow, M., Kumar, Y., Labeda, D. P. \& Sembiring, L. (2007). The Streptomyces violaceusniger clade: a home for streptomycetes with rugose ornamented spores. Antonie van Leeuwenhoek 92, 173-199.

Jeon, Y. S., Chung, H., Park, S., Hur, I., Lee, J. H. \& Chun, J. (2005). jPHYDIT: a JAVA-based integrated environment for molecular phylogeny of ribosomal RNA sequences. Bioinformatics 21, 3171-3173.

Jones, K. L. (1949). Fresh isolates of actinomycetes in which the presence of sporogenous aerial mycelia is a fluctuating characteristic. J Bacteriol 57, 141-145.

Jukes, T. H. \& Cantor, C. R. (1969). Evolution of protein molecules. In Mammalian Protein Metabolism, vol. 3, pp. 21-132. Edited by H. N. Munro. New York: Academic Press.

Jurado, V., Laiz, L., Gonzalez, J. M., Hernandez-Marine, M., Valens, M. \& Saiz-Jimenez, C. (2005). Phyllobacterium catacumbae sp. nov., a member of the order 'Rhizobiales' isolated from Roman catacombs. Int J Syst Evol Microbiol 55, 1487-1490.

Kelly, K. L. (1958). Centroid notations for the revised ISCC-NBS color name blocks. J Res Nat Bur Standards U S A 61, 427.

Kim, B. J., Lee, S. H., Lyu, M. A., Kim, S. J., Bai, G. H., Chae, G. T., Kim, E. C., Cha, C. Y. \& Kook, Y. H. (1999). Identification of mycobacterial species by comparative sequence analysis of the RNA polymerase gene (rpoB). J Clin Microbiol 37, 1714-1720.

Kim, B.-J., Kim, C.-J., Chun, J., Koh, Y.-H., Lee, S.-H., Hyun, J.-W., Cha, C.-Y. \& Kook, Y.-H. (2004). Phylogenetic analysis of the genera Streptomyces and Kitasatospora based on partial RNA polymerase $\beta$ subunit gene $(r p o B)$ sequences. Int J Syst Evol Microbiol 54, 593-598.

Kluge, A. G. \& Farris, J. S. (1969). Quantitative phyletics and the evolution of anurans. Syst Zool 18, 1-32.

Koch, C., Kroppenstedt, R. M., Rainey, F. A. \& Stackebrandt, E. (1996). 16S ribosomal DNA analysis of the genera Micromonospora, Actinoplanes, Catellatospora, Catenuloplanes, Couchioplanes, Dactylosporangium, and Pilimelia and emendation of the family Micromonosporaceae. Int J Syst Bacteriol 46, 765-768.

Kroppenstedt, R. M. (1985). Fatty acid and menaquinone analysis of actinomycetes and related organisms. In Chemical Methods in Bacterial Systematics (Society for Applied Bacteriology Technical Series vol. 20), pp. 173-199. Edited by M. Goodfellow \& D. E. Minnikin. New York: Academic Press.
Kumar, S., Tamura, K. \& Nei, M. (2004). MEGA3: integrated software for molecular evolutionary genetics analysis and sequence alignment. Brief Bioinform 5, 150-163.

Lechevalier, M. P., De Bièvre, C. \& Lechevalier, H. A. (1977). Chemotaxonomy of aerobic actinomycetes: phospholipid composition. Biochem Syst Ecol 5, 249-260.

Minnikin, D. E., Alshamaony, L. \& Goodfellow, M. (1975). Differentiation of Mycobacterium, Nocardia, and related taxa by thin-layer chromatographic analysis of whole-organism methanolysates. J Gen Microbiol 88, 200-204.

Minnikin, D. E., O’Donnell, A. G., Goodfellow, M., Alderson, G., Athalye, M., Schaal, A. \& Parlett, J. H. (1984). An integrated procedure for the extraction of bacterial isoprenoid quinones and polar lipids. J Microbiol Methods 2, 233-241.

National Bureau of Standards (1964). ISCC-NBS Color Manual Charts Illustrated with Centroid Colors. Supplement to NBS Circular 553. Washington, DC: US Government Printing Office.

O'Donnell, A. G., Falconer, C., Goodfellow, M., Ward, A. C. \& Williams, E. (1993). Biosystematics and diversity amongst novel carboxydotrophic actinomycetes. Antonie van Leeuwenhoek 64, 325340.

Rosselló-Mora, R. \& Amann, R. (2001). The species concept for prokaryotes. FEMS Microbiol Rev 25, 39-67.

Saitou, N. \& Nei, M. (1987). The neighbor-joining method: a new method for reconstructing phylogenetic trees. Mol Biol Evol 4, 406425.

Sambrook, J., Fritsch, E. F. \& Maniatis, T. (1989). Molecular Cloning: a Laboratory Manual, 2nd edn. Cold Spring Harbor, NY: Cold Spring Harbor Laboratory.

Sasser, M. (1990). Identification of bacteria by gas chromatography of cellular fatty acids, MIDI Technical Note 101. Newark, DE: MIDI Inc.

Schaal, K. P. (1985). Identification of clinically significant actinomycetes and related bacteria using chemical techniques. In Chemical Methods in Bacterial Systematics, pp. 359-381. Edited by M. Goodfellow \& D. E. Minnikin. London: Academic Press.

Shirling, E. B. \& Gottlieb, D. (1966). Methods for characterization of Streptomyces species. Int J Syst Bacteriol 16, 313-340.

Shomura, T., Kojima, M., Yoshida, J., Ito, M., Amano, S., Totsugawa, K., Niwa, T., Inouye, S., Ito, T. \& Niida, T. (1980). Studies on a new aminoglycoside antibiotic, dactimicin. I. Producing organism and fermentation. J Antibiot 33, 924-930.

Shomura, T., Yoshida, J., Miyadoh, S., Ito, T. \& Niida, T. (1983). Dactylosporangium vinaceum sp. nov. Int J Syst Bacteriol 33, 309-313.

Shomura, T., Amano, S., Tohyama, H., Yoshida, J., Ito, T. \& Niida, T. (1985). Dactylosporangium roseum sp. nov. Int J Syst Bacteriol 35, 1-4.

Shomura, T., Amano, S., Yoshida, J. \& Kojima, M. (1986). Dactylosporangium fulvum sp. nov. Int J Syst Bacteriol 36, 166-169.

Staneck, J. L. \& Roberts, G. D. (1974). Simplified approach to identification of aerobic actinomycetes by thin-layer chromatography. Appl Microbiol 28, 226-231.

Tan, G. Y. A., Ward, A. C. \& Goodfellow, M. (2006). Exploration of Amycolatopsis diversity in soil using genus-specific primers and novel selective media. Syst Appl Microbiol 29, 557-569.

Thawai, C., Tanasupawat, S. \& Kudo, T. (2008). Micromonospora pattaloongensis sp. nov., isolated from a Thai mangrove forest. Int $J$ Syst Evol Microbiol 58, 1516-1521.

Thiemann, J. E., Pagani, H. \& Beretta, G. (1967). A new genus of the Actinoplanaceae: Dactylosporangium gen. nov. Arch Mikrobiol 58, 4252.

Uchida, K., Kudo, T., Suzuki, K. \& Nakase, T. (1999). A new rapid method of glycolate test by diethyl ether extraction, which is 
applicable to a small amount of bacterial cells of less than one milligram. J Gen Appl Microbiol 45, 49-56.

Vobis, G. (1989). Genus Dactylosporangium Thiemann, Pagani \& Beretta. In Bergey's Manual of Systematic Bacteriology, vol. 4, pp. 2429-2433. Edited by S. T. Williams, M. E. Sharpe \& J. G. Holt. Baltimore: Williams \& Wilkins.

Vobis, G. (2006). The genus Actinoplanes and related genera. In The Prokaryotes: a Handbook on the Biology of Bacteria, 3rd edn, vol. 3, pp.
623-653. Edited by M. Dworkin, S. Falkow, E. Rosenberg, K. H. Schleifer \& E. Stackebrandt. New York: Springer.

Wayne, L. G., Brenner, D. J., Colwell, R. R., Grimont, P. A. D., Kandler, O., Krichevsky, M. I., Moore, L. H., Moore, W. E. C., Murray, R. G. E. \& other authors (1987). International Committee on Systematic Bacteriology. Report of the ad hoc committee on reconciliation of approaches to bacterial systematics. Int $J$ Syst Bacteriol 37, 463-464. 